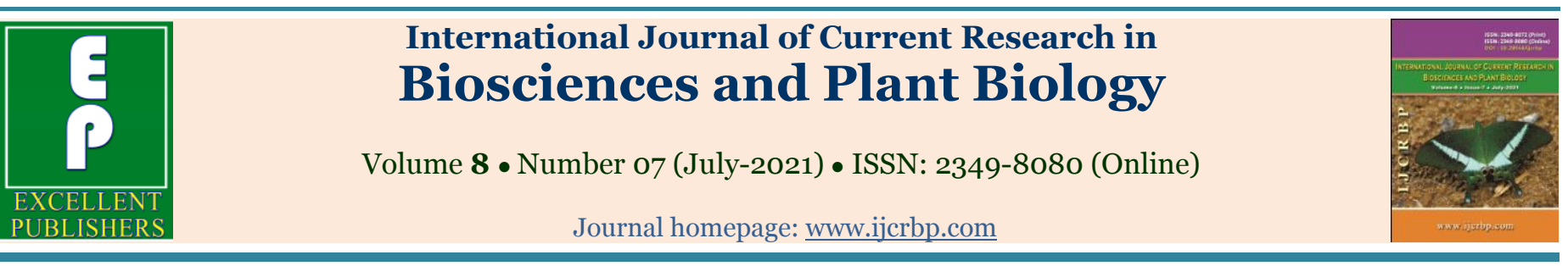

Original Research Article

doi: $\underline{\text { https://doi.org/10.20546/ijcrbp.2021.807.004 }}$

\title{
Lindernia dubia (L.) Pennell (Linderniaceae): A new record for the flora of Gujarat State, India
}

\author{
Kishan I. Prajapati ${ }^{1 *}$, Darsh K. Patel ${ }^{1}$, Ekta P. Joshi ${ }^{2}$ \\ ${ }^{I}$ Vande Vasundhara Research Laboratory, Bhuj, Kachchh, Gujarat - 370 001, India \\ ${ }^{2}$ R. R. Lalan Collage, Bhuj, Kachchh, Gujarat-370 001, India \\ *Corresponding author; e-mail: vandevasundharalab@gmail.com
}

\begin{tabular}{ll}
\hline Article Info & Abstract \\
\hline Keywords: & Lindernia dubia (L.) Pennell has been reported first time from two districts (i.e., Sabarkantha and \\
$\begin{array}{l}\text { Lindernia dubia } \\
\text { New record }\end{array}$ & Kheda) of Gujarat State. It was recorded along with the wetland margins from both the localities. \\
$\begin{array}{l}\text { Sabarkantha } \\
\text { Kheda }\end{array}$ & Detail morphological description, distribution, flowering and fruiting period, remarks and macro \\
Gujarat & \\
& \\
\hline & Received: 21 May 2021 • Revised: 22 June 2021 • Accepted: 28 June 2021 • Published Online: 06 July 2021 \\
\hline
\end{tabular}

\section{Introduction}

Traditionally the genus Lindernia Allioni (1762) is classified as a member of the Scrophulariaceae family. The newly outlined Linderniaceae are a monophyletic group that has emerged in the course of the disintegration of the Scrophulariaceae in the past years (Pennell, 1935; Rahmanzadeh et al., 2005; Fischer et al., 2013; Schmotzer, 2015). The genus Lindernia comprises about 100 species (Fischer, 1999), distributed throughout the old and new world (Lewis.2000). A total of 28 species of Lindernia are reported from IndoBurma (Mukherjee, 1945) and 31 taxa reported from India, among them 25 are known from South India (Sivarajan and Mathew, 1983; Murugan et al., 2002;
Tandyekkal and Mohanan, 2010; Ratheesh et al., 2012; Prasad and Sunojkumar, 2014).

From Jan. 2019, frequent field trips were conducted to study the aquatic flora of selected wetlands of Gujarat State. During the extensive botanical exploration in Pariej wetland of Kheda District-central part of Gujarat, the first author observed an interesting semi aquatic species growing on wet ditches of lake margin along with grasses, sedges and many wetland plants. The Pariej wetland is one of the eight wetlands of national importance identified in Gujarat state by the Ministry of Environment, Forest and climate change (MoEF \& CC) Government of India. After critical observation of morphological features as well as floral characters the 
specimen identified as a Lindernia dubia (L.) Pennell with the help of different flora and authentic literature (Prasad and Sunojkumar, 2014; Krishnasamy and Arumugam, 2015). Subsequently, the second author also reported the same specimen from Himatnagar taluka, Sabarkantha district. The district Sabarkantha is situated in the North-Eastern part of Gujarat state. The district is very important for rich floristic diversity as well as ethnobotanical plant species and pre-dominated by the tribal areas (i.e., Khedbrahma, Vijaynagar forest etc). In addition, a brief description, phenology, remarks, and photographs provided for easy field identification. The present localities of the Lindernia dubia (L.) Pennell. in Gujarat are shown in Fig. 1. The herbarium specimens were deposited at Vande Vasundhara Research Laboratory, Bhuj-Kachchh.

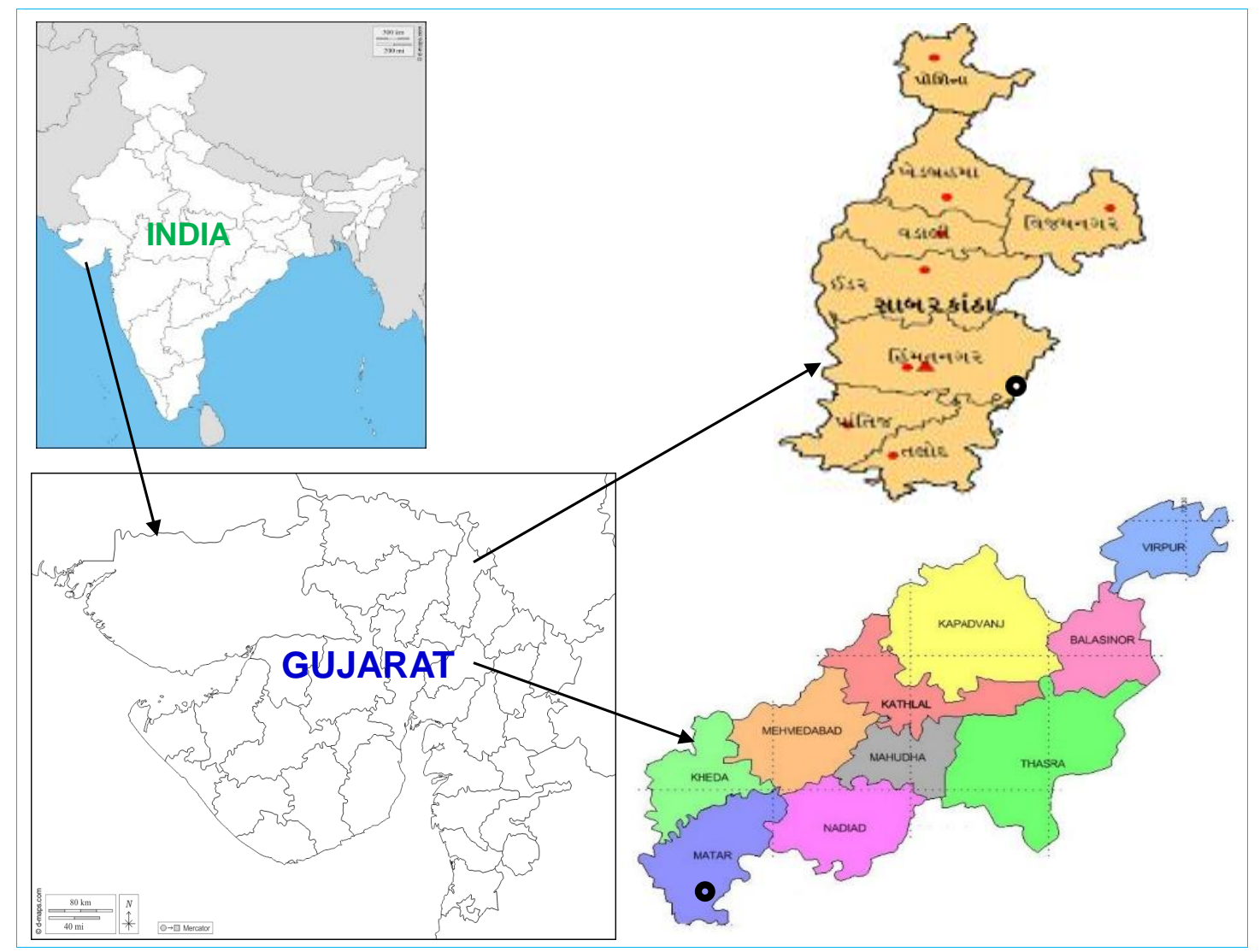

Fig. 1: Location of Lindernia dubia (L.) Pennell. in Gujarat.

\section{Materials and methods}

\section{Study area}

Kheda district:Pariej wetland $\left(22^{\circ} 33^{\prime} 00^{\prime \prime} \mathrm{N}, 72^{\circ} 38^{\prime} 00^{\prime \prime}\right.$ E) is situated in Matar taluka of Kheda district. The district is famous for high quality of tobacco production. Pariej wetland is considered as an Important Bird and Biodiversity Area (IBA) of India and also a Rank-1 (i.e., top ranking) wetland from biodiversity point of view as per the national wetland prioritization by Salim Ali Centre for Ornithology and Natural History (Vijayan, 2004; Suthar, et al., 2019; Joshi, 2018). Pariej wetland is covering 445 ha area and one of the largest man-made freshwater wetland in Gujarat. This perennial wetland linked with the canal and supplies drinking water to 52 surrounding villages around Pariej through pipelines. The wetland is covered by full of aquatic vegetation. Typha angustata Bory \& Chaub. constitutes the most dominant hydrophytic on fringes.

Sabarkantha district: The study area $\left(23^{\square} 39^{\prime} 34.4 " \mathrm{~N}\right.$, $73 \square 1000.6 "$ E) is situated in Himatnagar taluka of Sabarkantha district. During the extensive botanical exploration for study the aquatic plants diversity of Himatnagar taluka, the authors visited an interesting unexplored wetland area located on the way of Gambhoi-Bhiloda highway near Gopalkunj village. So 
far, this unrecorded annual wetland explored recently by authors and documented a good number of aquatic plants; among them one interesting not common species Hemiadelphus polyspermus (Roxb.) Ness is also recorded as strongly associated with Lindernia dubia (L.) Pennell. The district Sabarkantha is famous for rich floristic diversity which was explored by various plant taxonomists (Sexton and Sedegwick, 1918; Yogi, 1970; Bhatt and Sabnis, 1987; Punjani, 1997; Patel, 2003; Panday, 2011; Parmar, 2012). After literature review of mentioned literatures, we concluded that the species was not recorded from Sabarkantha and Kheda district.

\section{Results and discussion}

In order to check the identity, through the florals and published articles literature of Gujarat, there are 12 species of Lindernia those have been reported from Gujarat state (Cooke, 1958; Shah, 1978; Raghvan at el., 1981; Bole and Pathak 1988; GEC, 1996; Pandey and Singh, 1999; Singh and Parabia, 2003; Meena, 2004, Patel et al., 2021). It is concluded that the species was unrecorded so far from Gujarat state. Hence, Lindernia dubia (L.) Pennell. as a new addition record to the flora of Gujarat.

\section{Taxonomy}

Lindernia dubia (L.) Pennell, in Acad. Nat. Sci. Phil. Monogr. 1: 141. 1935. Gratiola dubia L. Sp. Pl. 17. 1735 .

Herb, annual, erect, 5-20 cm long; Rooting at the lower node; Stem herbaceous, light green, 4-angeled, glabrous, much branched near the base; Leaves sessile, basal ones larger, smaller towards the apex, 0.5-2 ×0.1$1.5 \mathrm{~cm}$, ovate or ovate-elliptic, upper lanceolate, 3 nerved from base, nerves mainly distinct on lower larger leaves, base usually rounded or cuneate-attenuate, apex acute, margin entire; Flowers solitary, axillary, pedicel cylindrical, glandular hairy, equalling or longer than the leaves, 5-10 mm long. Calyx deeply 5-lobed, 3-4 mm long, linear or lanceolate, apex acute, sparsely glandular, sepals basally connate. Corolla 6-10 mm long, white, tube 4.5-5 $\mathrm{mm}$ long, the upper lip slightly emarginate at the apex, lower lip 3-lobed, lobes rounded. Androecium 4, the anterior 2 staminodes and posterior 2 perfect, anthers 2-lobed, posterior stamens coherent below the upper lip when staminodes covered with yellowish glands throughout, free at apex. Ovary 1.1-1.4 mm long, ellipsoid, style 2.5-3 mm long, stigma 2-lamellate. Capsule 2-5 mm, ellipsoid or obliquely ellipsoid, obtuse to acute at apex, glabrous, matured capsules yellow, persistent calyx present, seed numerous (Fig. 2).

Flowering and fruiting: July to December (recorded during field survey in the April month).

Distribution: Kerala, Andhra Pradesh, Madhya Pradesh, Tamil Nadu, recently in Gujarat.

Specimen examined: India. Gujarat: Kheda district, Matar taluka, Pariej wetland, Kishan Prajapati, 11 April 2021, VVRL-005; Sabarkantha district, Himatnagar taluka, near to Gopalkunj village, Darsh Patel, 22 May 2021, KD-VVRL-006.

\section{Remarks and habitat}

This plant species recorded in wet ditches and margins of the wetlands. Our scientific observation concluded that the specimen was strongly associated with four major families like Cyperaceae, Poaceae, Acanthaceae and Scrophulariaceae. In first locality Pariej: We have noticed that the sedges are dominant in habitat like Bulbostylis sp. and Cyperus sp. Pteridophyte species Marsilea minuta is also recorded as a strongly associated with L. dubia. In second locality Gopalkunj: It has been observed that Peplidium maritimum (L.) Wetstt., Fimbristylis sp., Cyperus compressus L., Cyperus laevigatus L., Bergia ammannioides Roxb. and Paspalum sp. is strongly associated with L. dubia. In addition, the rich population of three not common aquatic plant species named Uticularia gibba L. var. exolete (R. Br) Tylor, Ludwigia adscendens (L.) Hara. and Nymphoides cristatum (Roxb.) O. Ktze. has been noticed.

\section{Conclusions}

The numbers of the individuals are different from the both localities i.e., 4 individuals were recorded from Pariej wetlands and up to 30 individuals were recorded from Gopalkunj wetland. The area of Gopalkunj wetland and surrounding localities are being used by pastoralist communities for grazing their domestic animals, and overgrazing pressure may lead pressure on development of seeds of this species. So, we proposed to create awareness campaign among the surrounding villages on this plant species rarity and conservation significance. 


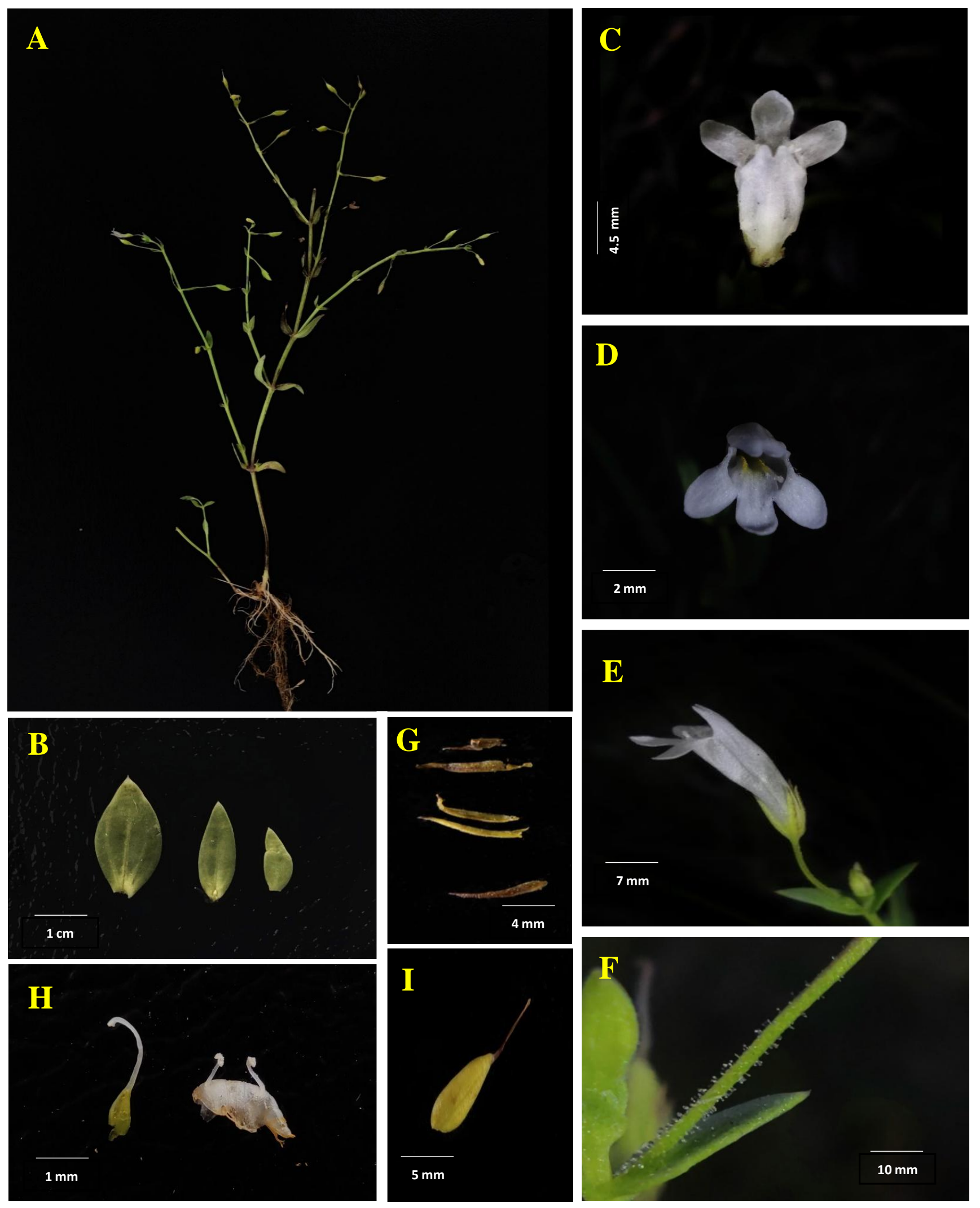

Fig. 2: Lindernia dubia (L.) Pennell: A. Habit; B. Leaf; C, D and E. Different views of flowers (viz., top view, front view and side view); F. Glandular pedicel; G. Calyx; H. Androecium and gynoecium: I. Capsule. 


\section{Conflict of interest statement}

Authors declare that they have no conflict of interest.

\section{Acknowledgement}

The authors are thankful to Dr. P. Sunojkumar, Department of Botany, University of Calicut, Kerala, India for confirmation of the species. We are thankful to Dr. Kalpesh Ishnava, ARIBAS, New Vallabh Vidyanagar, Anand, Gujarat, for valuable imputes during the study. We are also thankful to Mr. Yashesh Shah, Secure Nature Society, Mandvi-Kachchh, Gujarat for preparations of figures. The first author is grateful to Dr. Pankaj Joshi, Sahjeevan, Bhuj-Kachchh, Gujarat for providing courageous support throughout the study.

\section{References}

Allioni, C., 1762. Stirpium aliquot descriptiones. Mélanges de Philosophie et de Mathématique de la Société Royale de Turin. 3, 176-185.

Bhatt, R. P., Sabnis, S. D., 1987. Contribution to the Ethnobotany of Khedbrahma region of North Gujarat. J. Econ. Tax. Bot., 9(1): 139-145.

Bole P. V, Pathak J. M., 1988. Flora of Saurashtra, PartII \& III. Botanical Survey of India, Calcutta.

Cooke, T., 1958. Flora of Presidency of Bombay. Vol, I-III. Botanical Survey of India, Culcutta (Reprinted).

Fischer, E., 1999. Two new species of Lindernia (Scrophulariaceae) from East and South-East Africa and taxonomic remarks on the Lindernia rotundifolia-complex. Bulletin du Jardin botanique national de Belgique/Bulletin van de Nationale Plantentuin van Belgie., 67: 361-370.

Fischer, E., Schäferhoff, B., Müller, K., 2013. The phylogeny of Linderniaceae - The new genus Linderniella, and new combinations within Bonnaya, Craterostigma, Lindernia, Micranthemum, Torenia and Vandellia. Willdenowia, 43: 209-238.

Joshi, K., 2018. Comparison of aquatic avifauna of two important wetlands of central Gujarat - Pariej (Kheda District) and Kanewal (Anand District), India. Int. Res. J. Biol. Sci., 7(7): 1-5

Krishnasamy, J., Arumugam, R., 2015. American species of Lindernia dubia (L.) Pennell-occurrence in India. Biol. Forum, 7(1): 48-51.

Lewis, D. Q., 2000. A revision of the New World species of Lindernia (Scrophulariaceae). Castanea, 65(2): 93-122.
Meena, S. L., Pandey, R. P., 2004. A reassessment of phytodiversity of Gujarat State: Floristic composition and analysis, vegetation, threatened and rare taxa and their conservation strategies. J. Econ. Taxon. Bot., 28(4): 867-894.

Mukherjee, S.K., 1945. Revision of the Indo-Burmese species of Lindernia All. J. Indian Bot. Soc., 24: 127-134.

Murugan, C., Sivalingam, R., Benniamin, A., Kannan, S.G.D., 2002. Lindernia srilankana Cramer \& Philcox (Scrophulariaceae) - a new record for India. Rheedea, 12(2): 155-157.

Pandey, R. P., Singh, V., 1999. Gujarat: Floristic diversity and conservation strategies in India. In: Mudgal, V., Hajara, P. K. (Eds.), Flora of India 2, Botanical Survey of India, Kolkata, pp.775-806.

Pandey, V. B., 2011. Plant species diversity and their ethnobotanical study in tribal area of Bhiloda (West) forest range of Sabarkantha District (North Gujarat). A Ph.D., thesis submitted to Hemchandracharya North Gujarat University, Patan, Gujarat.

Parmar, P. J., 2012. A checklist of the vascular plants of Sabarkantha District, Gujarat, India. Nelumbo, 54: 92-137.

Patel, S. K., 2002. A Contribution to the Flora of Meghraj and Malpur Talukas of Sabarkantha District of North Gujarat. A Ph. D., thesis submitted to Hemchandracharya North Gujarat University, Patan, Gujarat.

Patel, S., Nayi, T., Punjani, B., Chaudhary, Y., Pandey, V., Desai, P., 2021. Lindernia tamilnadensis MG Prasad \& Sunojk. (Linderniaceae): A new record to the flora of Gujarat state, India. Int. J. Adv. Scient. Res., 6(2): 1-3.

Pennell, F.W., 1935. The Scrophulariaceae of eastern temperate North America. Academy of Natural Sciences of Philadelphia Monographs, 1, 137-159

Pilo, B., Pathak, B. J., Kumar, B. A., Muruksan, V. K., Vinod, K. R., Kumari, S., 1996. Biological diversity of Gujarat-Current knowledge. Gujarat Ecological Commission, Vadodara.

Prasad, M. G., Sunojkuma, P., 2014. First record of Lindernia dubia (Linderniaceae) in India and reduction of Lindernia nelliyampathiensis as one of its synonyms. Phytotaxa, 184(3): 165-169.

Punjani, B. L., 1997. An Ethnobotanical Study of Tribal Areas of District Sabarkantha (Gujarat). A Ph.D., thesis submitted to Hemchandracharya North Gujarat University, Patan, Gujarat.

Raghavan, R. S., Wadhwa, B. M., Ansari, M. Y., Rao, R. S., 1981. Checklist of the plants of Gujarat. 
Records-Botanical Survey of India.

Rahmanzadeh, R., Müller, K., Fischer, E., Bartels, D., Borsch, T., 2005. The Linderniaceae and Gratiolaceae are further lineages distinct from the Scrophulariaceae (Lamiales). Plant Biol., 7: 67-78.

Ratheesh Narayanan, M.K., Sunil, C.N., Nandakumar, M.K., Sujana, K.A., Jayesh, P.J., Anil Kumar, N., 2012. Lindernia madayiparense (Linderniaceae) A new species from Kerala, India. Int. J. Plant Anim. Environ. Sci., 2: 59-62.

Schmotzer, A., 2015. Occurrence of Lindernia dubia in the Ipoly valley (Hungary and Slovakia). Stud. Bot. Hung., 46: 77-89.

Sexton, W. T., Sedgwick, L. J., 1918. Plants of Northern Gujrat. Rec. Bot. Sur. Ind., 6(7): 209-323.

Shah, G. L., 1978. Flora of Gujarat state. Part I and II. Sardar Patel University Press. Vallabh Vidyanagar, Gujarat.

Singh, A. P., Parabia, M., 2003. The floral diversity of
Gujarat State: A review. Indian For., 129(12): 14611469.

Sivarajan, V.V., Mathew, P., 1983. The genus Lindernia All. (Scrophulariaceae) in India. J. Bombay Nat. Hist. Soc., 80: 131-140

Suthar, A. M., Tatu, K., Gujar, R., Kamboj, R. D., 2019. A comparative account of diversity of hydrophytes in some inland wetlands (Pariej, Kanewal and Wadhwana) of Central Gujarat. Res. Rev. J. Life Sci., 9(2): 39-43.

Tandyekkal, D. \& Mohanan, N., 2010. Lindernia ciliata ssp. sivarajanii (Scrophulariaceae) from India. Nord. J. Bot., 28(2): 202-205.

Vijayan, V. S., 2004. Inland wetlands of India: conservation priorities. Salim Ali Centre for Ornithology and Natural History.

Yogi, D. V., 1970. A contribution to the flora of North Gujarat. A Ph. D., thesis submitted to Sardar Patel University, Vallabh Vidyanagar, Gujarat.

\section{How to cite this article:}

Prajapati, K. I., Patel, D. K., Joshi, E. P., 2021. Lindernia dubia (L.) Pennell (Linderniaceae): A new record for the flora of Gujarat State, India. Int. J. Curr. Res. Biosci. Plant Biol., 8(7): 23-28.

doi: https://doi.org/10.20546/ijcrbp.2021.807.004 